\title{
Renal impairment in $\beta$ thalassemia major patients receiving repeated blood transfusion
}

\author{
Riadi Wirawan*, Simon Kusnandar*, Abas Suherli*, Djajadiman Gatot ${ }^{f}$
}

\begin{abstract}
Abstrak
Thalassemia $\beta$ mayor adalah penyakit yang disebabkan oleh kelainan sintesis rantai polipeptida $\beta$ yang diturunkan secara otosom resesif. Pengobatan thalassemia $\beta$ mayor pada umumnya berupa pemberian transfusi berulang, yang mengakibatkan penumpukan besi dan berakhir dengan hemokromatosis. Penumpukan besi dapat terjadi pada organ tubuh antara lain ginjal. Tujuan penelitian ini untuk mengetahui adanya gangguan fungsi ginjal pada penderita thalassemia $\beta$ mayor berumur 15-28 tahun yang telah mendapatkan 6 unit packed red cells. Pada penelitian ini telah diperiksa kadar besi serum (SI) dan daya ikat besi total (TIBC) serta kadar mikroalbumin dan $\beta 2$-mikroglobulin $(\beta 2-m)$ dalam urin. Hasil yang didapat 94,7\% penderita menunjukkan peningkatan saturasi transferin dan $40 \%$ diantaranya disertai hemokromatosis; 73,4\% disertai mikroalbuminuria, 1,3\% dengan albuminuria dan $21,3 \%$ dengan peningkatan $\beta 2-m$ urin. Jumlah kasus dengan kelainan ginjal dijumpai pada 78,6\%. (Med J Indones 2003; 12: 215-223)
\end{abstract}

\begin{abstract}
$\beta$-thalassemia major is a disease caused by $\beta$ polypeptide chain synthesis disorder which is inherited in an autosomal recessive manner from both parents and which is marked by little or no $\beta \square$-globin chain synthesis. Treatment for $\beta$-thalassemia major patients is by giving repeated blood transfusions, which causes iron accumulation, leading to hemochromatosis. Iron accumulation can occur in various body organ, including the kidneys. The aim of this study was to investigate the existence of renal impairment in $\beta$ thalassemia major patients. The subjects of this study were $\beta$-thalassemia major patients aged $15-28$ years old who had received 6 units of packed red cells or more within 6 months. In this study, urine and serum samples of the subjects were taken and examined. Assay of serum iron was performed with Hitachi 737. Results were that $94.7 \%$ patients showed an increase in transferrin saturation and $40 \%$ of them had hemochromatosis; $73.4 \%$ had microalbuminuria; $1.3 \%$ had albuminuria and $21.3 \%$ had increased urinary 32 microglobulin $(\beta 2-m)$. A total of $78.6 \%$ of patients showed renal impairment. Conclusion of this study suggested that glomerular dysfunction happens in an earlier stage of the disease process. The high incidence of microalbuminuria is also attributed to defective ability of the proximal tubular cells to reabsorb protein besides dysfunction of the glomeruli. (Med J Indones 2003; 12: 215-223)
\end{abstract}

Keywords: $\beta \square$-thalasemia major, repeated blood transfusion, renal impairment

There are several means to assess renal function. The most frequently used test to estimate glomerular filtration rate (GFR) is the creatinine clearance test (CCT). Glomerular permeability can be evaluated through urinary albumin assessment, while renal tubular function is usually assessed by urinary $\beta 2$ microglobulin $(\beta 2-\mathrm{m})$ measurement. Non-protein nitrogen (NPN) levels in blood, such as urea, creatinine and uric acid usually reflects excretory functions of the kidneys. The ability of the kidneys to

\footnotetext{
* Department of Clinical Pathology, Faculty of Medicine, University of Indonesia/Dr. Cipto Mangunkusumo, Jakarta, Indonesia

${ }^{f}$ Department of Child's Health, Faculty of Medicine, University of Indonesia/Dr. Cipto Mangunkusumo, Jakarta, Indonesia
}

retain or excrete water can also be measured. ${ }^{1,2,3}$

Ineffective hematopoeisis, hemolysis, increased iron absorption and repeated blood transfusion in $\beta$ thalassemia major patients will increase deposition of iron. Iron accumulation can occur in nearly all kinds of cells, but especially the reticuloendothelial cells in organs such as the spleen, liver, and bone marrow; it also occurs in the parenchymal cells in the heart, liver, kidneys, pancreas, and endocrine glands such as the Langerhans islets, the pituitary gland, testicles and ovaries. $^{4,5,6,7}$ Inappropriate management in preventing iron accumulation will result in organ damage due to free radicals and lipid cell membrane peroxidation which is called hemochromatosis. ${ }^{5,8}$ 
Lack of data and research in the field of renal function in $\beta$ thalassemia major patients receiving repeated blood transfusion and its relation to transferrin saturation led us to study the renal function through assessment of urinary $\beta 2$-microglobulin and albumin levels, and correlate them with transferrin saturation.

\section{METHODS}

We evaluated $75 \quad \beta$ thalassemia major patients attending the Thalassemia Center, Department of Child Health, Medical School, University of Indonesia, Dr. Cipto Mangunkusumo General Hospital between July 2001 and August 2001. Subjects were 15 years of age or older, willing to participate in this study, and had received 6 units of packed red cells or more within 6 months. Blood and urine samples were collected on the morning prior to the transfusion. ${ }^{9}$

All subjects had been well informed and had given their consent to participate in the study. The Committee for Research Ethics, Medical School, University of Indonesia had approved the study protocol.

Subjects with hypertension who were on medication that decreases creatinine excretion such as salicylates, cimetidine, trimethroprim, spironolactone and amiloride, were excluded from this study. ${ }^{2,3}$

Five $\mathrm{ml}$ of blood was drawn from the antecubital vein by sterile syringe without anticoagulant, and serum was obtained in a vacutainer after centrifugation at $4000 \mathrm{rpm}$ for 10 minutes. Ten $\mathrm{ml}$ of midstream urine samples were collected in an appropriate urine container on the same morning. All procedures were done preceeding the transfusion.

Reagent kits from Elitech were used for the analysis of serum iron (SI), total iron binding capacity (TIBC), ALT and AST, using the Hitachi 737 chemistry analyzer.

Microalbuminuria was measured by the pyrogallol red method; urine creatinine was measured by the enzymatic method from Elitech on the Hitachi 737. Microparticle Enzyme Immunoassay (MEIA) from Abbott Diagnostics was applied in $\beta 2$-microglobulin $(\beta 2-\mathrm{m})$ determinations using the IMx. All laboratory examinations were done at the Department of Clinical Pathology, Medical School, University of Indonesia, Dr. Cipto Mangunkusumo General Hospital.
Preliminary calibration of Hitachi 737 for SI, TIBC, ALT, AST, creatinine and microalbuminuria was conducted with a calibrator from Roche (cat no. 152298). Calibrator $\beta 2-\mathrm{m}$ from Abbott (cat no. 2201-01) was used to calibrate the IMx for $\beta 2$-microglobulin determinations.

Within run and between day precision tests was run on the Hitachi 737 using Precinorm U (PN) cat. no. 153213 and Precipath U (PP) cat. no. 152117, and for $\beta 2$-microglobulin on the IMx with a three level control (cat. no. 2201-10).

A master table describing individual data: name, age, gender, and laboratory results (SI, TIBC, transferrin saturation, AST, ALT, microalbuminuria, $\beta 2-\mathrm{m}$, albumin/creatinine ratio, and $\beta 2-\mathrm{m} /$ creatinine ratio) was made and a descriptive analysis done. Kolmogorov-Smirnov test for data distribution was carried out to determine the statistical correlation between $\beta 2-\mathrm{m}$, microalbuminuria and transferrin saturation. If the data distribution were normal, Pearson correlation test would be applied otherwise, the Spearman test would be used. ${ }^{10}$ All statistical tests were carried out using Statistical Product and Service Solution (SPSS) version 10.0 for Windows.

\section{RESULTS}

Within-run and between-day precision of all tests run on the Hitachi 737 with Precinorm U (PN) from Roche yielded the following results: AST $(2.12 \%$ and $2.09 \%)$, ALT $(2.93 \%$ and $3.63 \%)$, creatinine $(3.29 \%$ and $3.40 \%)$, SI ( $4.22 \%$ and $4.57 \%)$, and TIBC ( $4.71 \%$ and $4.28 \%$ ). The results of within-run and betweenday precision of microalbumin run on the Hitachi 737 with microalbumin control were $2.10 \%$ and $1.92 \%$ (Table 1).

Accuracy tests run on the Hitachi 737 with PN from Roche yielded the following results: AST $(-0.79 \%)$, ALT $(+2.25 \%)$, creatinine $(-0.66 \%)$, SI $(+1.33 \%)$ and TIBC $(+2.10 \%)$. The results of accuracy test for microalbumin on the Hitachi 737 using $100 \mathrm{mg} / \mathrm{dL}$ albumin solution was $+2.00 \%$. (Table 1 )

Within-run and between-day precision of all tests run on the Hitachi 737 with Precipath U (PP) from Roche yielded the following results: AST $(1.50 \%$ and $1.85 \%)$, ALT $(1.75 \%$ and $2.31 \%)$, creatinine $(3.11 \%$ and $3.30 \%)$, SI (3.28\% and $3.74 \%)$, and TIBC (4.52\% and $4.33 \%$ ). (Table 1) 
The results of accuracy tests run on the Hitachi 737 with PP from Roche were: AST $(+3.04 \%)$, ALT $(+2.71 \%)$, creatinine $(+4.30 \%)$, SI $(+4.78 \%)$ and TIBC $(+1.16 \%)$. (Table 1$)$

The results of within run precision for B2-M on the IMx for Low (L), Medium (M) and High (H) controls were: $7.08 \%, 4.53 \%$ and $5.38 \%$ respectively. The accuracy of the test for $\mathrm{L}, \mathrm{M}$, and $\mathrm{H}$ controls was: $+6.65 \%,+4.38 \%$ and $+7.33 \%$ respectively (Table 2 ).

At least $73 \beta$ thalassemia major patients who met the criteria for this study were needed ${ }^{3}$, in order to show the proportion of elevated transferrin saturation, the minimal number of patients required to determine the correlation between elevated transferrin saturation and increased $\beta 2-\mathrm{m}$ secretion and microalbuminuria was $29 .^{11}$ The number of patients participating in this study was 75 .

The profile of the participants were as follows; age between 15 and 28 years, body mass index between 11.0 and 23.4, transferrin saturation between 40.6 and $96.6 \%$, AST and ALT activity between 24 and 276 U/l, and 16 and $292 \mathrm{U} / 1$ respectively. Urinary albumin excretion was between 4 and $360 \mathrm{mg} / \mathrm{dl}$, while albumin/creatinine ratio was between $0.1-4.7$ $\mathrm{mg} / \mathrm{mg}$. Urinary $\beta 2-\mathrm{m}$ excretion was between $260-$ $109.650 \mathrm{ng} / \mathrm{dL}$, while $\beta 2-\mathrm{m} /$ creatinine ratio was between $5.9-830 \mathrm{ng} / \mathrm{mg}$. (Table 3 )

Table 1. Accuracy, within-run and between day precision using PN and PP Roche ${ }^{\circledR}$ for SI, TIBC, AST, ALT, creatinine, and microalbumin control for microalbuminuria on the Hitachi 737

\begin{tabular}{llllllll}
\hline Parameter & CV $(\%)$ & \multicolumn{2}{c}{ Within-run CV $(\%)$} & \multicolumn{2}{c}{ Between-day CV (\%) } & \multicolumn{2}{c}{ Within-rund (\%) } \\
& NCCLS & PN & PP & PN & PP & PN & PP \\
\hline AST & 3.57 & 2,12 & 1,50 & 2,09 & 1,85 & $-0,79$ & 3,04 \\
ALT & 3.97 & 2,93 & 1,75 & 3,63 & 2,31 & 2,25 & 2,71 \\
Creatinine & 8.9 & 4,22 & 3,11 & 3,40 & 3,30 & $-0,66$ & 4,30 \\
SI & 15 & 4,71 & 3,28 & 4,57 & 3,74 & 1,33 & 4,78 \\
TIBC & 15 & 4,41 & 4,52 & 4,28 & 4,33 & 2,10 & 1,16 \\
Microalbuminuria & 7.5 & 2,10 & & 1,94 & & 2,00 & \\
\hline
\end{tabular}

Table 2. Precision and accuracy of $\beta 2-m$ tests on the IMx using $\beta 2-m$ control Abbott ${ }^{\circledR}$

\begin{tabular}{cccc}
\hline$\beta 2-\mathrm{m}$ & $\begin{array}{c}\text { Manufacturer CV } \\
(\%)\end{array}$ & $\mathrm{CV}(\%)$ & $\mathrm{d}(\%)$ \\
\hline Low & 7,4 & 7,08 & 6,65 \\
Medium & 7,6 & 4,53 & 4,38 \\
High & 5,4 & 5,38 & 7,33 \\
\hline
\end{tabular}

Table 3. Participants profile ( $\mathrm{n}=75$ subjects)

\begin{tabular}{llllll}
\hline Parameter & Unit & $\mathrm{n}$ & Minimum & Maximum & Reference value \\
\hline Age & Years & 75 & 15 & 28 & \\
Transferrin Saturation (TS) & $\%$ & 75 & 40,6 & 96,6 & $<55$ \\
AST & U/L & 75 & 24 & 176 & $<37$ \\
ALT & U/L & 75 & 16 & 292 & $<41$ \\
Microalbuminuria & $\mathrm{mg} / \mathrm{dL}$ & 75 & 4 & 360 & $30-140$ \\
Urine Albumin/Creatinine ratio & $\mathrm{mg} / \mathrm{mg}$ & 75 & 0,1 & 4,7 & $<0,3$ \\
Urine $\beta$ 2-microglobulin & $\mathrm{ng} / \mathrm{dL}$ & 75 & 260 & 109.560 & 15.400 \\
Urine $\beta 2-\mathrm{m} /$ Creatinine ratio & $\mathrm{ng} / \mathrm{mg}$ & 75 & 5,9 & 830,0 & $<166$ \\
\hline
\end{tabular}


Seventy-one out of 75 subjects $(94.7 \%)$ had a transferrin saturation of more than $55 \%$, while 30 subjects $(40 \%)$ had hemochromatosis (transferrin saturation of more than $55 \%$ associated by elevated transaminase activity of more than twice the reference value), refer to Figure 1.
Glomerular impairment was found in 56 subjects $(74.7 \%)$, in which $55(73.4 \%)$ subjects showed microalbuminuria, and albuminuria in one subject (1.3\%), refer to Figure 2.

Tubular impairment (increased $\beta 2-\mathrm{m}$ excretion) was found in 16 subjects (21.3\%), refer to Figure 3.

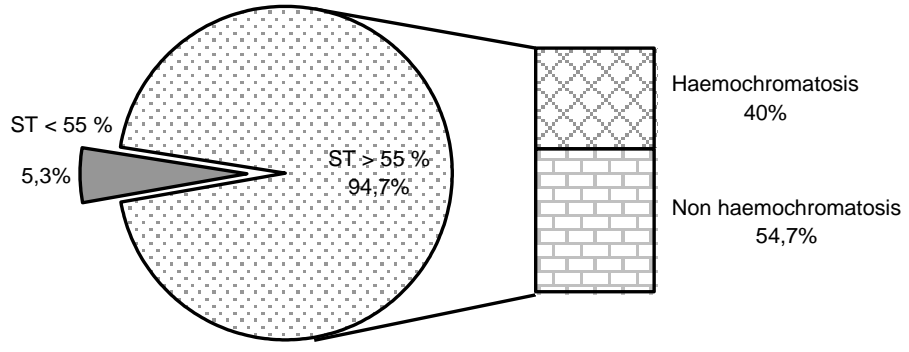

Figure 1. Proportion of transferrin saturation

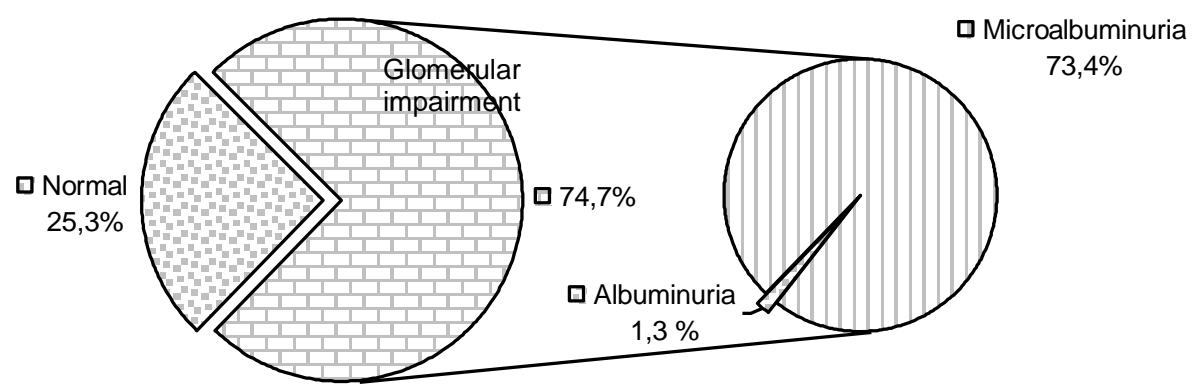

Figure 2. Proportion of glomerular impairment

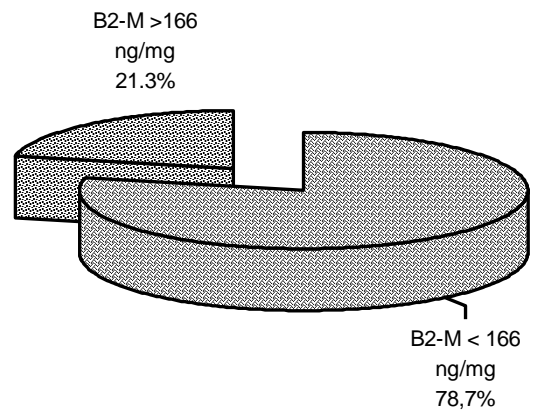

Figure 3. $\beta 2-m$ excretion 
Forty-three $(57.3 \%)$ subjects had microalbuminuria, $12(16.0 \%)$ subjects had microalbuminuria with increased $\beta 2-\mathrm{m}$ excretion, $3(4.0 \%)$ subjects had increased $\beta 2-\mathrm{m}$ excretion and only $1(1.3 \%)$ subject showed albuminuria with increased $\beta 2-\mathrm{m}$ excretion. A total of $59(78.6 \%)$ subjects showed renal impairment.(Fig 4.)

The scatter diagram in figure 5 and 6 shows glomerular impairment occurring at the age of 15 years, while tubular involvement is seen at 16 years of age.

The Kolmogorov-Smirrnov (K-S) test showed a normal distribution $(p>0.05)$. The Pearson's Correlation test to determine the correlation between transferrin saturation and microalbuminuria and $\beta 2-\mathrm{m}$ excretion were as follows: there was no correlation between transferrin saturation and microalbuminuria, $\beta 2-\mathrm{m}$ excretion, urine albumin/creatinine ratio, urine $\beta 2-\mathrm{m}$ /creatinine ratio. (Table 4)
Table 4. Results of correlation tests between transferrin saturation and microalbuminuria, albumin/creatinine ratio, $\beta 2-\mathrm{m}$ excretion and $\beta 2-\mathrm{m} /$ creatinine ratio

\begin{tabular}{lll}
\hline Parameter & $r^{*}$ & $p^{* *}$ \\
\hline Microalbuminuria & 0,024 & 0,759 \\
Albumin/creatinine ratio & $-0,088$ & 0,281 \\
$\beta 2-\mathrm{m}$ & $-0,025$ & 0,749 \\
$\beta 2-\mathrm{m} /$ creatinine ratio & $-0,146$ & 0,065 \\
\hline
\end{tabular}

* Strongly correlated $(r>0,80)$, correlated $(r=0,60-0,80)$, weak correlation $(r=0,40-0,59)$, very weak correlation $(<0,40)^{20}$

** $p<0,05=$ significant

We divided the subjects into two groups. The first group consisted of patients with hemochromatosis, the second group consisted of patients without hemochromatosis. We did a correlation test with the Kendall-tau b, and found no correlation between hemochromatosis and microalbuminuria, and albumin / creatinine ratio were found. (Table 4.) There was a very weak positive correlation $(r=0.327$ dan $p=0.004)$ between hemochromatosis and $\beta 2-\mathrm{m}$ excretion, and also with $\beta 2$ $\mathrm{m} /$ creatinine ratio $(r=0.298$ dan $p=0.010)$. 


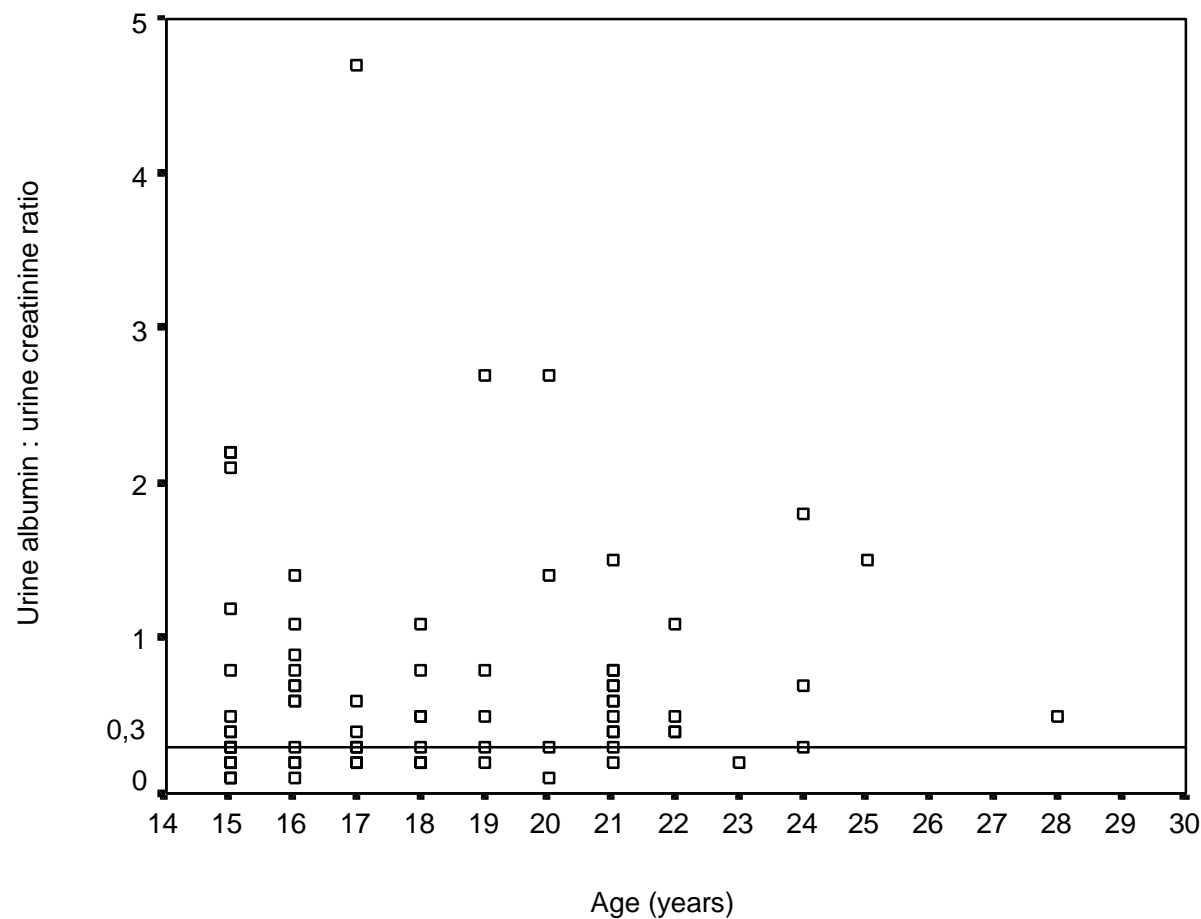

Figure 5. Scatter diagram showing glomerular impairment in $\beta$-thalassemia major patients

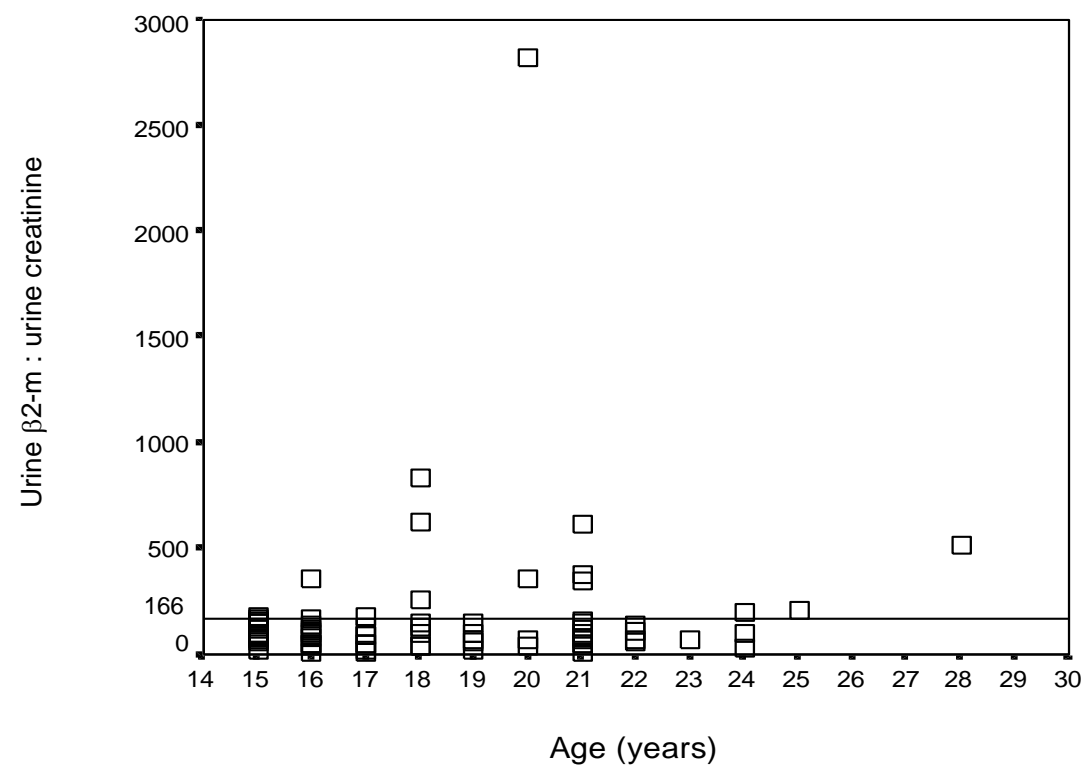

Figure 6. Scatter diagram showing tubular impairment in $\beta$-thalassemia major patients 


\section{DISCUSSION}

Precision and accuracy for all test run on the Hitachi 737 met the requirements of the National Committee for Clinical Laboratory Standards (NCCLS) in International External Quality Assessment Scheme (IEQAS). ${ }^{12}$ Precision and accuracy for $\beta 2-\mathrm{m}$ determination on the IMx also met the required recommendation of the manufacturer. ${ }^{13}$

The reason for choosing an age group of more than 15 years old is the high probability that this group has had hemochromatosis. Without regular iron chelating regiment, $\beta$ thalassemia major patients will develop organ damage due to iron deposit, which is called hemochromatosis. ${ }^{5}$ The normal reference range for transferrin saturation is $20-45 \%$, in hemochromatosis the transferrin saturation is $\geq 55 \%$ accompanied by increased ALT and AST activity of more than twice the reference value. ${ }^{7,14}$ Seventy one subjects $(94.7 \%)$ out of 75 that participate in this study had a transferrin saturation of more than $55 \%, 30(40.0 \%)$ had hemochromatosis (Fig 1). This confirmed earlier studies that $\beta$ thalassemia major patients receiving regular blood transfusion will experience iron accumulation, each unit of transfused blood contains 200 to $250 \mathrm{mg}$ iron. ${ }^{4}$ After one year of receiving regular (once in $2-4$ weeks) blood transfusion, iron accumulation will be found in the hepatic parenchym. ${ }^{6}$ The amount of iron may exceed the serum transferrin capacity to bind iron, non transferrin bound iron forms free radicals and cause tissue damage through oxidative process in the cell membrane lipid, amino acid, protein, and nucleic acid. ${ }^{4,5,6,7}$ Organs usually influenced by iron accumulation are the liver, pancreas, heart, joints, and endocrine glands. ${ }^{15}$

Besides damage to the cell membrane, oxidative process can also damage the mitochondria, lysosome and smooth endoplasmic reticulum (SER), ${ }^{15}$ causing elevated serum transaminase activity, which is considered as an indicator of hemochromatosis.

The normal glomerular capillary discriminates on the basis of size and acts as an electrostatic barrier to prevent albumin, globulin and other large molecule plasma proteins to pass. Proteins with a molecular weight less than 20.000 daltons could pass in minute amounts through the glomerular capillary, to be reabsorbed by the proximal tubular cells. Small molecules such as alpha2-microglobulin, $\beta 2-\mathrm{m}$, apoprotein, certain enzymes, and peptides, are normally excreted in small amounts into the urine. The average normal human excretes 30 to $130 \mathrm{mg}$ protein/day. ${ }^{1,2,3}$

Pyrogallol red-molybdate is a dye that gives a color reaction with albumin with a sensitivity of $97 \%$, but also reacts with $\gamma$-globulin with a sensitivity of $70 \%$, Bence Jones type $\lambda$ with a sensitivity of $52 \%$, and $68 \%$ for type $\kappa$, and $98 \%$ for hemoglobin. ${ }^{16}$

Microalbuminuria is a condition in which urinary albumin excretion exceeds the normal limits but is less than clinical albuminuria $(20-200 \mu \mathrm{g} / \mathrm{min}$ or 30 $-300 \mathrm{mg} / 24 \mathrm{~h}$ ), which is $30-140 \mu \mathrm{g}$ albumin $/ \mathrm{mL}$ urine. ${ }^{17}$ To avoid 24 hour urine collections, the albumin/creatinine ratio is recommended. In an earlier study, Suryaningsih ${ }^{18}$ found that to predict albuminuria the albumin/creatinine ratio is better than urinary albumin determination, and correlated with 24 hour urinary albumin excretion. Microabuminuria is represented by an albumin/creatinine ratio of 0.3 to 3 $\mathrm{mg} / \mathrm{dL}$, while albuminuria is depicted when the albumin/creatinine ratio is more than $3 \mathrm{mg} / \mathrm{dL} .{ }^{19}$

In our study the range of urinary albumin excretion was $4-360 \mathrm{mg} / \mathrm{dL}$ with an albumin/creatinine ratio of $0,1-4,7 \mathrm{mg} / \mathrm{mg}$. Microalbuminuria was found in 55 (73.4\%) subjects and albuminuria in one (1.3\%) subject, $19(25.3 \%)$ subjects had normal urinary albumin excretion (Fig 7).

Landing et all, as cited by Zhou et all, ${ }^{10}$ found hemosiderin deposit in the parietal epithelial cells and visceral glomerulus in patients with hemosiderosis. They also found large amounts of hemosiderin deposit in the proximal and distal renal tubuli.

There are two factors leading to albuminuria and microalbuminuria in $\beta$ thalassemia major patients. First, iron deposit in the kidneys damages the glomerulus, causing an increased filtration of large molecular weight (> 20.000 daltons) plasma proteins which exceeds the tubular capacity to reabsorb. Second, indirectly through the diabetic kidney as a complication of iron accumulation in the pancreas.

$\beta 2-\mathrm{m}$ is a protein with a molecular weight of 11.800 dalton, first extracted from a patient with tubular proteinuria by Berggard et all ${ }^{13,21}$ in 1968. This protein $(\beta 2-\mathrm{m})$ is found on the human cell surface expressing the major histocompatibility complex (MHC) class I, as a light chain attached to the heavy 
chain of the MHC class I antigen. After the MHC class I antigen is released from the cell surface, it undergoes a proteolytic process and $\beta 2-m$ enters the circulation as a monomer, and can be found in the serum, and other body fluids. ${ }^{13,21} \beta 2-\mathrm{m}$ filtered through the glomerular membrane is nearly completely reabsorbed by the proximal tubular cells and degraded. Urinary $\beta 2-\mathrm{m}$ excretion is a sensitive parameter to evaluate the proximal tubular function, and can be used to differentiate tubular dysfunction from glomerular dysfunction. ${ }^{13,21,22}$

It has been reported that large amounts of hemosiderin deposit are found in the proximal and distal tubuli, causing atrophy of the proximal tubule in $\beta$ thalassemia major patients. ${ }^{20}$

Our study revealed a urinary $\beta 2-\mathrm{m}$ excretion of between $260-109.560 \mathrm{ng} / \mathrm{dL}$ and a $\beta 2-\mathrm{m} /$ creatinine ratio of between $5.9-830.0 \mathrm{ng} / \mathrm{mg}$. Tubular dysfunction was found in $16(21.3 \%)$ patients, with a $\beta 2-\mathrm{m} /$ creatinine ratio $>166 \mathrm{ng} / \mathrm{mg}$.

Reichert et $\mathrm{al}^{18}$ studied 30 patients with membranous nephropathy, and found 11 out of 14 patients with $\beta 2$ $\mathrm{m}$ excretion of $>500 \mathrm{ng} / \mathrm{min}$ suffered from renal dysfunction, but only 2 out of 16 patients with $\beta 2-\mathrm{m}$ excretion of $<500 \mathrm{ng} / \mathrm{min}$ suffered from renal dysfunction. Urinary $\beta 2-\mathrm{m}$ excretion of $>500 \mathrm{ng} / \mathrm{min}$ has a $79 \%$ positive predictive value, and an $88 \%$ negative predictive value with $85 \%$ sensitivity and $82 \%$ specificity.

Ong-ajyooth et $\mathrm{al}^{23}$ who, studied $97 \beta$ thalassemia $\mathrm{HbE}$ patients and 27 normal controls found a significant increase in urinary protein excretion, $\beta 2-\mathrm{m}$ excretion, and $N$-acetyl beta-D-glucoaminidase (NAG). It is assumed that iron pile up caused tissue oxidative stress, which is expressed by increased malonyldialdehyde (MDA) in serum and urine.

Our study revealed $16(21.3 \%)$ patients with tubular dysfunction; urinary $\beta 2-\mathrm{m}$ determination could be used as a tool to assess renal tubular function.

It has been mentioned in earlier studies that $\beta$ thalassemia major patients receiving repeated blood transfusion suffers from large amounts of haemosiderin deposits in the proximal and distal tubuli, the parietal epithelial cells, and visceral glomerulus. ${ }^{20}$
In our study, most patients (55 or $73.4 \%$ ) had microalbuminuria and one with albuminuria, while increased $\beta 2-\mathrm{m}$ excretion was found in only $16(21 \%)$ patients. This suggests that glomerular dysfunction occurs in an earlier stage of the disease process. There is, of course, a probability that tubular dysfunction already existed before $\beta 2-\mathrm{m}$ excretion is increased which caused microalbuminuria through reduced ability of the tubular cells to reabsorb albumin from the filtrate. Our study also revealed that renal dysfunction could be detected in patients as young as 15 years old. (Figure 10 and 11)

Statistical analysis was used to look for correlation between increased transferrin saturation and microalbuminuria and increased urinary $\beta 2-\mathrm{m}$ excretion, but no correlation was found between those parameters. Meanwhile a very weak positive correlation between hemochromatosis and increased urinary $\beta 2-\mathrm{m}$ excretion and $\beta 2-\mathrm{m} /$ creatinine ratio was found. This means that $\beta$ thalassemia major patients with hemochromatosis are prone to renal dysfunction and this finding is in accordance with the autopsy findings of Grossman et $\mathrm{al}^{24}$ and Landing et al, as cited by Zhou et $\mathrm{al}^{20}$ who reported histological renal tubular damage.

\section{CONCLUSIONS}

A study involving $75 \beta$ thalassemia major patients receiving more than 6 units of blood transfusion within the last 6 months revealed, $94.7 \%$ had increased transferrin saturation and $40.0 \%$ had hemochromatosis. Seventy-three point four percent had microalbuminuria, one $(1.3 \%)$ had albuminuria, $21.3 \%$ had increased urinary $\beta 2-\mathrm{m}$ excretion. A total of $78.6 \%$ of all patients showed renal dysfunction.

No correlation was found between transferrin saturation and microalbuminuria, while significant but very weak positive correlation was found between hemochromatosis and increased urinary $\beta 2-\mathrm{m}$ and $\beta 2$ $\mathrm{m} /$ creatinine ratio. Although there was no correlation between hemochromatosis and microalbuminuria, $(73.4 \%)$ of patients with microalbuminuria was quite high. This suggested that glomerular dysfunction happens (earlier in the course of disease) in an earlier stage of the disease process. Probably the high incidence of microalbuminuria is also attributed to defective ability of the proximal tubular cells to reabsorb protein besides dysfunction of the glomeruli. 
Microalbumin could be suggested as a relatively sensitive parameter to detect renal dysfunction. This study verifies that hemochromatosis can cause renal dysfunction.

We suggest testing for microalbumin to determine any renal damage by iron deposit in the kidneys, or if possible urinary $\beta 2-\mathrm{m}$ estimation as a routine test for $\beta$ thalassemia major patients to determine therapeutic desferrioxamine (DFO) dosage, because DFO can cause renal toxicity.

\section{REFERENCES}

1. Krieger NJ, Sherrard DJ. Practical fluids and electrolytes. $1^{\text {th }}$ ed. Norwalk : Appleton \& Lange. $1991:$ p $1-36$

2. Pincus MR, Preuss HG, Henry JB. Evaluation of renal function, water, electrolytes, acid-base and blood gases. In: Henry JB ed.19 $9^{\text {th }}$ ed. Clinical diagnosis and management by laboratory methods. Philadelphia WB Saunders Co. 1996: p 134-61

3. Rose BD. Clinical physiology of acid-base and electrolyte disorders. $4^{\text {th }}$ ed. New York : McGraw-Hill International ed. $1994:$ p $3-65$

4. Andrews NC. Disorders of iron metabolism. N Eng J Med $341: 26 ; 1999: 1986-95$

5. Hershko C. Pathophysiology of iron overload. Education session 13 : red cell and iron. ISH-EHA Combined haematology congress. Amsterdam. $1998: 150$ - 3

6. Oliveri NF. The $\beta$ - Thalassemia. N Eng J Med. 1999; 341 : $99-109$

7. Powell LW, George K, McDonnell SM, Kowdleg KV. Diagnosis of hemochromatosis. Ann. Intern. Med.129; $1998: 925-31$

8. De Sanctis V, Wonke B editors. Growth and endocrine complications in thalassemia. Rome : mediprint ; 1998

9. Lee MH, Means RT. Extremely elevated serum ferritin levels in a University Hospital : associated diseases and clinical significance. The Am. Journal of Med. 1995 ; 98 : $566-71$

10. Saunders DB. Trapp GR. Estimating and comparing mean. In : Basic clinical biostatistic. Canada. A Lange medical book. 1994 : p 896 - 909
11. Machin D, Champbell MJ, Fayers PM, Pinol APY. Sample size tables for clinical studies. $2^{\text {nd }}$ ed. Blackwell Science Ltd. 1997 : 168 - 73

12. Scheme for general clinical chemistry. International external quality assesment.

13. Anonymous. Leaflet B2-microglobulin dari Abbott diagnostic. cat. no. 2201-20. 1993

14. Boehringer Mannheim GmbH. Diagnosis of liver disease. Translation from the revised German edition. 1989: 3 - 34

15. Bonkovsky HL, Lambrecht RW. Pathophysiology of liver disease. Iron induced liver injury. Clin in Liver Disease. $2000 ; 4: 121-31$

16. Watanabe N, Kami S, Ohbuko A et al. Urinary protein as measured with a pyrogallol red-molybdate methode for determining total urinary protein. Clin Chem. 1989 : 35 : $2233-6$

17. Suryaatmadja M. Microalbuminuria. Urinalysis Symposium PDS PatKlin - HKKI 1991 : 15 - 20 (In Indonesian)

18. Suryaningsih V. Albumin/creatinine ratio in the morning urine sample as an alternative method for 24-hours urinary albumin excretion in NIDDM patients. Thesis. Department of Clinical Pathology, Medical School, University of Indonesia, Jakarta. 2000 (In Indonesian)

19. Shihabi ZK, Konen JC, O’Connor ML. Albuminuria Vs urinary total protein for detecting chronic renal disorders. Clin Chem. $1991 ; 37: 621-4$

20. Zhou XJ, Vaziri ND, Pandian D, Wang ZQ, Mazowiecki M, Liao SY et al. Urinary concentrating defect in experimental hemochromatosis. J Am Soc Nephro 1996 ; 7 (1) : $128-35$

21. Karlsson, FA, Wibell L, Evrin PE. $\beta_{2}$-microglobulin in clinical medicine. Scand J Clin Lab Inves. 1980 ; 40, supl (154) : $27-37$

22. Miyata T, Jadoul M, Kurokawa K, van Yperle de Strihou C. Reviews : beta-2 microglobulin in renal disease. J Am Soc Nephro $1998 ; 9: 1723$ - 35

23. Ong-ajyooth L, Malasit P, Ong-ajyooth S, Fucharoen S, Pootrakul P, Vasuvattakul S et al. Renal function in adult beta-thalassemia/Hb E disease. Nephron. 1998 ; 78 (2) : $156-61$

24. Grosman H, Dische R, Winchester P, Canalis V. Renal enlargement in thalassemia major. Radiology 100 ; 1971 : $645-8$ 